\title{
$\beta$-Butyltellanyl Carbonyl Compounds: A Useful Source of Masked Metal Homoenolates
}

\author{
Alcindo A. Dos Santos* and João V. Comasseto \\ Instituto de Química, Universidade de São Paulo, Av. Prof. Lineu Prestes, $n^{\circ}$ 748, 05508-900 São Paulo - SP, Brazil \\ Cianocupratos de ordem superior e homoenolatos de lítio secundários, foram eficientemente \\ gerados a partir de $\beta$-butil teluro cetais e submetidos a reação com benzaldeido e 2-cicloexen-1-ona. \\ Secondary higher order cyanocuprates and lithium homoenolates, were efficiently generated \\ from $\beta$-butyltellanylketals and reacted with benzaldehyde and 2-cyclohexen-1-one.
}

Keywords: tellurides, tellurium / lithium exchange, secondary lithium homoenolates and higher order cyanocuprates

\section{Introduction}

Homoenolate anions are important synthons in the Umpolung concept. ${ }^{1}$ Unlike the enolate anions, the homoenolate anions cannot be stoichiometrically generated by deprotonation of a carbonyl compound, since the $\mathrm{pk}_{\mathrm{a}}$ value of the $\beta$-hydrogen is only very slightly lowered. ${ }^{2}$ In addition, the reactive homoenolates $\mathbf{1}$, especially lithium and sodium derivatives, spontaneously cyclize to the corresponding cyclopropanolate tautomer 2 (Scheme 1), ${ }^{2}$ which does not react as a carbon-nucleophile with standard electrophiles.

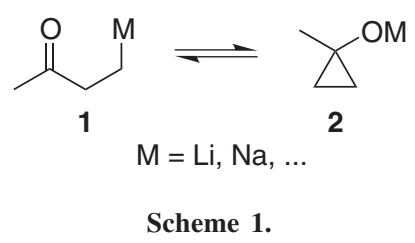

Although the $\alpha$-enolization of carbonyl compounds is readily carried out under mild conditions to yield high equilibrium concentrations of $\alpha$-enolates, vigorous conditions are required to give low concentrations of shortlived intermediate homoenolates by $\beta$-deprotonation of nonenolizable ketones. ${ }^{2}$ This fact makes the direct $\beta$ deprotonation of carbonyl compounds an impracticable method for preparative purposes. The use of a masked carbonyl unit is an alternative to circumvent this problem. ${ }^{3}$

* e-mail: alcindo@iq.usp.br
However, this strategy is also limited to the presence of strongly electron-attracting substituents at the $\beta$-position to the masked carbonyl groups that promotes the stabilization of the carbanion formed. Classically, for this purpose nitro, ${ }^{4}$ phosphorus ${ }^{5}$ and sulphur ${ }^{6}$ based compounds are used. Moreover, this method requires previous preparation of the nitro, phosphorus or sulphur organic substrates and another further step, to remove reductively the activating group.

A simple strategy to circumvent this problem should be the preparation of $\beta$-butyltellanyl masked carbonyl compounds such as $\mathbf{3},{ }^{7}$ and their transformation into the corresponding lithium homoenolates through a tellurium/ lithium exchange reaction (Scheme 2). ${ }^{8}$

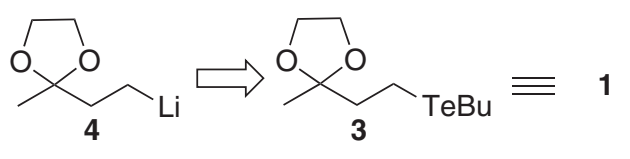

Scheme 2.

A general way to obtain compounds of type $\mathbf{3}$ should be the Michael addition of $n$-butyltellurol to $\alpha, \beta$ unsaturated ketones, as recently described by us, ${ }^{9}$ followed by a ketalization reaction.

The $n$-butyltellurol, generated in situ by reaction of elemental tellurium with $n$-BuLi in THF, followed by addition of a proton source such as ethanol or water, reacts rapidly with Michael acceptors. ${ }^{9}$ Under these conditions the $\beta$-butyltellanylketones 5 and $\mathbf{6}$ were successfully prepared in $86 \%$ and $89 \%$ yield respectively (Scheme 3). 


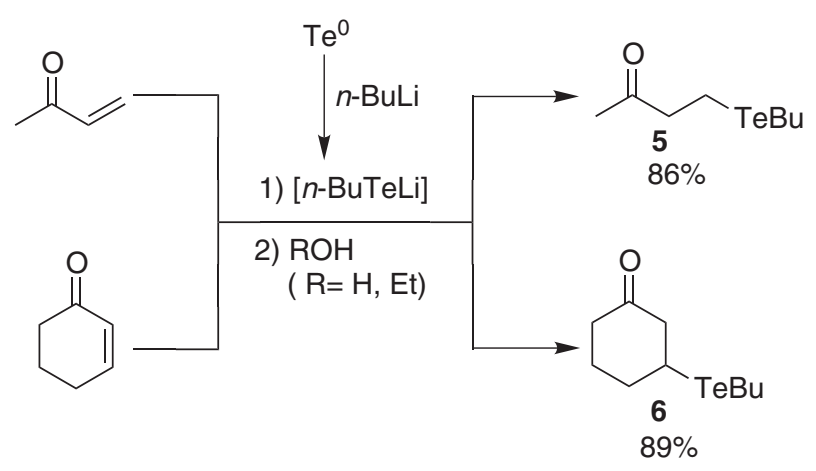

Scheme 3.

The $\beta$-butyltellanylketones 5 and $\mathbf{6}$ were converted into the corresponding $\beta$-butyltellanylketals $\mathbf{3}$ and $\mathbf{7}$ in high yields by reaction with ethylene glycol in benzene in a Dean-Stark apparatus (Scheme 4). ${ }^{9,10}$

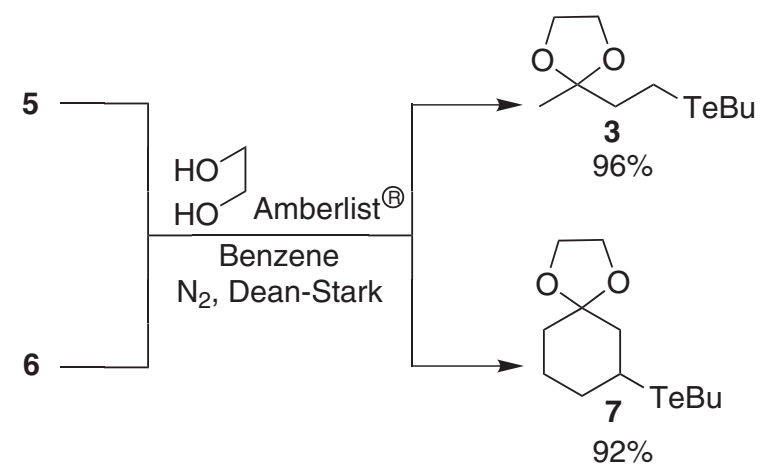

Scheme 4.

The light yellow tellurides $\mathbf{3}$ and $\mathbf{7}$ were transformed into the corresponding lithium masked homoenolates by reaction with $t$-butyllithium in THF at $-70{ }^{\circ} \mathrm{C}$. The tellurium/lithium exchange showed to be very fast even to generate a secondary anion.

Trapping the lithium anions with benzaldehyde afforded the corresponding alcohols $\mathbf{8}$ and $\mathbf{1 0}$ (Scheme 5). ${ }^{11}$ The lithium intermediates were also submitted to reaction with the copper soluble species $\mathrm{CuCN} .2 \mathrm{LiCl}^{12}$ producing the corresponding higher order cyanocuprates. ${ }^{13}$ Michael addition of these intermediates to 2-cyclohexen1 -one produced the corresponding saturated ketones (Scheme 5). ${ }^{13}$

All tellurides described in this paper are stable to the ambient light and can be manipulated in the air. Most of them are almost odourless or present a smell not more unpleasant them most of the laboratory chemicals normally used in an organic synthesis laboratory.

It is worthy of note that the dibutyltelluride originated in the tellurium/lithium exchange step, is totally compatible
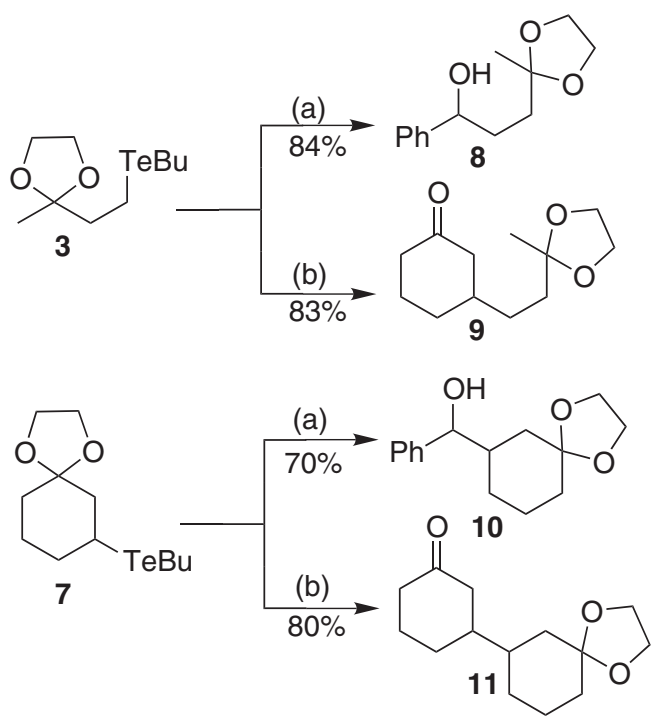

Scheme 5. (a): 1) $t$-BuLi (1 Equiv); 2) benzaldehyde. (b): 1) $t$-BuLi (1 Equiv.); 2) $\mathrm{CuCN} 2 \mathrm{LiCI}(0.5$ Equiv.); 3) 2-cyclohexen-1-one (1 Equiv.).

with all the subsequent operations. It can be easily eliminated in an odourless operation by washing the organic phase with a diluted sodium hypochlorite solution.

In conclusion, $\beta$-butyltellanyl carbonyl compounds are a very practical source of homoenolate equivalents.

\section{Acknowledgements}

The authors thank FAPESP for support.

\section{References}

1. Seebach, D.; Angew. Chem. Int. Ed. Engl. 1979, 18, 239; Evans, D. A.; Andrews, G. C.; Acc. Chem. Res. 1974, 7, 14; Hoppe, D.; Angew. Chem. Int. Ed. Engl. 1984, 23, 932.

2. Werstiuk, N. H.; Tetrahedron 1983, 39, 205; Ryu, I.; Sonoda, N.; J. Syn. Org. Chem. Jpn. 1985, 43, 112; Nakamura, E.; J. Syn. Org. Chem. Jpn. 1989, 47, 931.

3. Büchi, G.; Wüest, H.; J. Org. Chem. 1969, 34, 1122; for a recent review see: Yus, M.; Torregrosa, R.; Pastor, I. M.; Molecules 2004, 9, 330.

4. Bakuzis, P.; Bakuzis, M. L. F.; Weingartner, T. F.; Tetrahedron Lett. 1978, 2371; Crumbie, R. L.; Nimetz, J. S.; Mosher, H. S.; J. Org. Chem. 1983, 47, 4040; Corey, E. J.; Vlattas, I.; Anderson, N. H.; Harding, K.; J. Am. Chem. Soc. 1968, 90, 3247.

5. Corey, E. J.; Shimoji, K.; J. Am. Chem. Soc. 1983, 105, 1662; Bell, A.; Davidson, A. H.; Earnshaw, C.; Norrish, H. K.; Torr, R. S.; Warren, S.; J. Chem. Soc. Chem. Comm. 1978, 988; Cristau, H. J.; Chabaud, B.; Niangoran, C.; J. Org. Chem. 1983, 48, 1527. 
6. Kondo, K.; Tunemoto, T.; Tetrahedron Lett. 1975, 1007; Fayos, J.; Clardy, J.; Dolby, L. J.; Farham, T.; J. Org. Chem. 1977, 42, 1349.

7. The generation of $\mathbf{3}$ by a different approach and its transformation into a lithium homoenolate has been already described: Inoue, T.; Atarashi, Y.; Kambe, N.; Ogawa, A.; Sonoda, N.; Synlett 1995, 209.

8. Hiiro, T.; Kambe, N.; Ogawa, A.; Miyoshi, N.; Murai, S.; Sonoda, N.; Angew. Chem. Int. Ed. Engl. 1987, 26, 1187; for recent reviews see: Comasseto, J. V.; Barrientos-Astigarraga, R. E.; Aldrichimica Acta 2000, 33, 66; Petragnani, N.; Stefani, H. A.; Tetrahedron 2005, 61, 1613.

9. Zinn, F. K.; Righi, V. E.; Luque, S. C.; Formiga, H. B.; Comasseto, J. V.; Tetrahedron Lett. 2002, 43, 1625.

10. General procedure for the preparation of the $\beta$ butyltellanylketalls 3 and 7: To a two bottomed flask equipped with a Dean-Stark reflux apparatus were added the appropriate $\beta$-butyltellanylketone 5 or $6(5 \mathrm{mmol})$, benzene $(10 \mathrm{~mL})$, ethylene glycol ( $8 \mathrm{mmol}, 0.44 \mathrm{~mL})$ and Amberlist ${ }^{\circledR}(30 \mathrm{mg})$. The reaction mixture was refluxed under nitrogen atmosphere for 5 hours. The mixture was filtered and the residue washed with ethyl acetate. The solvents were removed under reduced pressure. The residue was purified by silica gel chromatography eluting with a mixture of hexane:ethyl acetate (15:1), to give 2-(2-(butyltellanyl)ethyl)-2-methyl-1,3-dioxolane (3). Yield: 1.43 g (96\%); ${ }^{1} \mathrm{H}$ NMR: (300 MHz, $\left.\mathrm{CDCl}_{3}, \mathrm{ppm}\right) \delta 3.95$ (m, $4 \mathrm{H}) ; 2.60-2.66$ (m, $4 \mathrm{H})$; 2.10-2.16 (m, $2 \mathrm{H}$ ); 1.72 (quint, $J$ $7.3 \mathrm{~Hz}, 2 \mathrm{H}$ ); 1.38 (sext, J 7.3 Hz, $2 \mathrm{H}$ ); 1.32 (s, 3H); 0.92 (t, $\left.J 7.3 \mathrm{~Hz}, 3 \mathrm{H}) ;{ }^{13} \mathrm{C} \mathrm{NMR:} \mathrm{(75} \mathrm{MHz,} \mathrm{CDCl}_{3}, \mathrm{ppm}\right) \delta 110.2$; $64.7 ; 42.1 ; 34.2 ; 25.0 ; 23.5 ; 13.3 ; 2.7 ;-5.6$; LRMS $m / z$ (rel. int.) 302 (M+, 3); 99 (4); 87 (100); 55 (15); 43 (58); IR (film) $v_{\text {max }} / \mathrm{cm}^{-1}: 2979 ; 2958 ; 2927 ; 2874 ; 1457 ; 1378 ; 1246 ; 1212$; 1040; 944; ${ }^{125} \mathrm{Te} \mathrm{NMR}\left(\mathrm{CDCl}_{3}, 157.79 \mathrm{MHz} / 298 \mathrm{~K} / \mathrm{Ph}_{2} \mathrm{Te}_{2}\right)$ $\delta$ (ppm) 263.3; Anal. Calc. for $\mathrm{C}_{10} \mathrm{H}_{20} \mathrm{O}_{2} \mathrm{Te}: \mathrm{C}, 40.13$; H, 6.68; Found: C, 40.35; H, 6.46. 7-butyltellanyl-1,4-dioxaspiro [4.5]hexane (7). Yield: $1.49 \mathrm{~g}(92 \%)$; ${ }^{1} \mathrm{H}$ NMR: (300 MHz, $\left.\mathrm{CDCl}_{3}, \mathrm{ppm}\right) \delta 3.94(\mathrm{t}, J 0.8 \mathrm{~Hz}, 4 \mathrm{H}) ; 3.30(\mathrm{~m}, 1 \mathrm{H}) ; 2.66$ (t, J 7.2 Hz, $2 \mathrm{H}) ; 2.00-2.23(\mathrm{~m}, 2 \mathrm{H}) ; 1.50-1.90$ (m, $8 \mathrm{H})$; 1.37 (sext, $J 7.2 \mathrm{~Hz}, 2 \mathrm{H}$ ); 0.91 (t, $J 7.2 \mathrm{~Hz}, 3 \mathrm{H}) ;{ }^{13} \mathrm{C} \mathrm{NMR}$ : (75 MHz, $\left.\mathrm{CDCl}_{3}, \mathrm{ppm}\right) \delta 108.7 ; 64.2 ; 44.8 ; 35.5 ; 34.5 ; 34.4$; 25.2; 25.0; 16.1; 13.4; 2.3; LRMS $\mathrm{m} / z$ (rel. int.) $328\left(\mathrm{M}^{+}, 10\right)$; 141 (87); 99 (100); 79 (12); 69 (18); 57 (13); 55 (44); 41 (70). IR(film) $v_{\max } / \mathrm{cm}^{-1}: 2953 ; 2933 ; 1448 ; 1356 ; 1299 ; 1164$; 1063; 1025; ${ }^{125} \mathrm{Te} \mathrm{NMR}\left(\mathrm{CDCl}_{3}, 157.79 \mathrm{MHz} / 298 \mathrm{~K} / \mathrm{Ph}_{2} \mathrm{Te}_{2}\right)$ $\delta$ (ppm) 423.31; Anal. Calc. for $\mathrm{C}_{12} \mathrm{H}_{22} \mathrm{O}_{2} \mathrm{Te}: \mathrm{C}, 44.30$; $\mathrm{H}$, 6.76; Found: C, 44.49; H, 6.72.

11. Typical procedure for the tellurium / lithium exchange reaction and capture of the resulting organolithium with benzaldehyde: to a solution of telluride 3 ( $1 \mathrm{mmol}, 0.29 \mathrm{~g})$ in THF $(5 \mathrm{~mL})$, at $-70{ }^{\circ} \mathrm{C}$ was added $t$-butyllithium $(1.0 \mathrm{mmol}, 0.89 \mathrm{~mL}, 1.12$ $\mathrm{mol} \mathrm{L}{ }^{-1}$ in pentane). After 5 min was added benzaldehyde (1 mmol, $0.1 \mathrm{~mL}$ ). The reaction mixture was allowed to warm to $0{ }^{\circ} \mathrm{C}$. The mixture was stirred for $1 \mathrm{~h}$ and then diluted with ethyl acetate $(5 \mathrm{~mL})$. The organic phase was sequentially washed with a diluted solution of sodium hypochlorite $(2 \times 5$ $\mathrm{mL})$ and brine $(2 \times 5 \mathrm{~mL})$, dried over magnesium sulphate, filtrated and evaporated. The residue was purified by column chromatography on silica gel using a 2:1 hexane:ethyl acetate mixture as eluent, to give 3-(2-methyl-1,3-dioxolan-2-yl)-1phenylpropan-1-ol (8). Yield: 0.18 g (84\%); CAS No: 16764451-1.

12. Knochel, P.; Yeh, M. C. P.; Berk, S. C.; Talbert, J.; J. Org. Chem. 1988, 53, 2390.

13. Typical procedure to prepare the higher order cyanocuprate and its reaction with 2-cyclohexen-1-one: To a solution of the lithium anion of telluride 7 ( $1 \mathrm{mmol}, 0.32 \mathrm{~g}$, generated by the same procedure described in ref. 11) at $-70{ }^{\circ} \mathrm{C}$, was added a solution of CuCN.2LiCl (0.5 mmol, $1 \mathrm{~mol}^{-1} / \mathrm{THF}, 0.5$ Equiv.). The resulting orange solution was stirred for $20 \mathrm{~min}$ at the same temperature and then 2-cyclohexen-1-one (1 Equiv.) was added in one portion. The resulting solution was stirred for $1 \mathrm{~h}$ at $-70{ }^{\circ} \mathrm{C}$ and then allowed to warm to $0{ }^{\circ} \mathrm{C}$. A solution of saturated aqueous ammonium chloride and ammonium hydroxide was added $(3 \mathrm{~mL})$ and the mixture was stirred for $40 \mathrm{~min}$. The organic phase was sequentially washed with a diluted solution of sodium hypochlorite $(2 \times 5 \mathrm{~mL})$ and then with brine $(2 \times 10 \mathrm{~mL})$, dried over magnesium sulphate, filtered and the solvents were removed. The residue was purified by silica gel chromatography using a 3:1 hexane:ethyl acetate mixture, to give a diastereomeric mixture of 3-(1,4-Dioxaspiro[4.5]dec-7-yl)-cyclohexanone (11). Yield: $0.19 \mathrm{~g}(80 \%)$; ${ }^{1} \mathrm{H}$ NMR: (300 MHz, $\mathrm{CDCl}_{3}$, ppm) $\delta$ 3.92-3.94 (m, 4H); 2.222.50 (m, $3 \mathrm{H})$; 2.04-2.13 (m, $2 \mathrm{H})$; 1.04-1.7 (m, $12 \mathrm{H})$; 0.860.98 (m, $1 \mathrm{H}) ;{ }^{13} \mathrm{C}$ NMR: (75 MHz, $\left.\mathrm{CDCl}_{3}, \mathrm{ppm}\right) \delta 212.1$; $109.4 ; 64.3 ; 64.2 ; 45.4 ; 44.0 ; 43.9 ; 41.5 ; 40.3 ; 38.7 ; 38.5$; $34.9 ; 34.8 ; 28.5 ; 28.4 ; 28.3 ; 25.5 ; 25.4 ; 23.2 ; 23.1$; LRMS $\mathrm{m} / \mathrm{z}$ (rel. int.) $238\left(\mathrm{M}^{+}, 2\right) ; 195$ (3); 141 (100); 113 (11); 112 (12); 99 (90); 86 (28); 55 (33); 42 (16); 41 (41); IR(film) $v_{\max } / \mathrm{cm}^{-1}: 2938 ; 2866 ; 1711 ; 1448 ; 1355 ; 1159 ; 1085 ; 919$; 516; Anal. Calc. for $\mathrm{C}_{14} \mathrm{H}_{22} \mathrm{O}_{3}: \mathrm{C}, 70.49$; H, 9.23; Found: C, 70.29; H, 9.11.

Received: March 17, 2005 Published on the web: April 29, 2005

FAPESP helped in meeting the publication costs of this article. 